\title{
Analisis utang luar negeri, sukuk, inflasi dan tingkat suku bunga terhadap pertumbuhan ekonomi indonesia Tahun 2014-2019
}

\author{
Septiana Sari \\ email : Septianas139@gmail.com \\ Fernaldi Anggadha Ratno \\ email : anggadharatno@iainsalatiga.ac.id \\ (Program Studi Ekonomi Syariah, Fakultas Ekonomi dan Bisnis Islam, IAIN Salatiga)
}

\begin{abstract}
ABSTRAK : Tujuan penelitian ini adalah untuk mengetahui pengaruh Utang Luar Negeri (X1), Sukuk (X2), Inflasi (X3) dan Tingkat Suku Bunga (X4) terhadap Pertumbuhan Ekonomi (Y). Jenis penelitian ini adalah penelitian kuantitatif dengan menggunakan analisis regresi sebagai analisis data dan menggunakan data sekunder yang berbentuk time series. Data yang telah diperoleh 72 sampel kemudian dianalisis menggunakan alat bantu aplikasi E-views 9. Data yang digunakan adalah data bulanan dari Utang Luar Negeri, Sukuk, Inflasi dan Tingkat Suku Bunga serta Pertumbuhan Ekonomi pada tahun 2014-2019. Berdasarkan hasil penelitian ini menunjukan bahwa secara parsial variabel dependen Utang Luar Negeri, Sukuk, Inflasi dan Tingkat Suku Bunga berpengaruh positif dan tidak signifikan terhadap variabel independen Pertumbuhan Ekonomi yang ditunjukan melalui Produk Domestik Bruto (PDB).
\end{abstract}

Kata Kunci : Utang Luar Negeri, Sukuk, Inflasi, Suku Bunga, Pertumbuhan Ekonomi.

ABSTRACT : The purpose of this study was to determine the effect of External Debt (X1), Sukuk (X2), Inflation (X3) and Interest Rates (X4) on Economic Growth (Y). This type of research is quantitative research using regression analysis as data analysis and using secondary data in the form of time series. The data obtained by 72 samples were analyzed using the E-views 9 application tool. The data used are monthly data from External Debt, Sukuk, Inflation and Interest Rates and Economic Growth in 2014-2019. Based on the results of this study, it shows that partially the dependent variable External Debt, Sukuk, Inflation and Interest Rates have a positive and insignificant effect on the independent variable of Economic Growth as shown by Gross Domestic Product (GDP).

Keywords : External Debt, Sukuk, Inflation, Interest Rates, Economic Growth. 


\section{PENDAHULUAN}

Suatu perekonomian dikatakan mengalami pertumbuhan apabila tingkat aktivitas ekonomi diwaktu tersebut lebih tinggi dari waktu sebelumnya. Dengan kata lain, perkembangan baru terjadi jika jumlah barang dan jasa secara fisik yang dihasilkan perekonomian tersebut bertambahn besar pada tahun-tahun berikutnya (Faroh, 2016). Pertumbuhan ekonomi adalah penambahan Gross Domestic Product (GDP) atau Produk Domestik Bruto (PDB), yang berarti peningkatan Pendapatan Nasional (PN) (Tambuhan, 2014)

Pertumbuhan ekonomi merupakan keadaan dimana suatu negara mampu meningkatkan output (hasil produksi ekonomi) berdasarkan kemajuan teknologi. Dari hal tersebut menunjukan adanya peningkatan produksi dalam suatu negara dan kemajuan teknologi untuk meningkatkan produktivitas. Pertumbuhan ekonomi yang tinggi dan berkelanjutan juga merupakan kondisi utama atau suatu keharusan bagi keberlangsungan pembangunan ekonomi, peningkatan kesejahteraan dan perubahan fundamental ekonomi suatu negara dalam periode jangka panjang. Berdasarkan perkembangan PDB dengan harga konstan, diketahui pada tahun 2014 sebesar Rp. 8.564.866 miliar dengan tingkat pertumbuhan ekonomi sebanyak 5.00 persen hingga mengalami kenaikan pada tahun 2019 sebesar Rp. 10.949.243,70 miliar dengan tingkat pertumbuhan ekonomi sebanyak 5.02 persen.

Untuk meningkatkan kualitas pertumbuhan ekonomi, Indonesia sendiri melakukan berbagai cara atau upaya, salah satunya dengan melakukan utang luar negeri. Menurut Bank Indonesia (BI), menyatakan bahwa posisi utang luar negeri Indonesia diajukan menurut kelompok peminjam (Pemerintahan, Bank Indonesia dan Swasta), sektor ekonomi, jenis mata uang, jenis kreditor, jenis instrumen serta jangka waktu, baik asal maupun sisa waktu. Dengan demikian, publikasi statistik utang luar negeri ini dapat digunakan untuk mengukur perkembangan berbagai sektor ekonomi dalam kaitannya dengan penyerapan utang luar negeri, risiko utang jangka pendek dan mengantisipasi kebutuhan valas (pasar valuta asing) untuk pembayaran utang. Berdasarkan fenomena yang terjadi pada tahun 2014 utang luar negeri mengalami kenaikan sebesar Rp. 293.770 miliar, hal tersebut dipengaruhi oleh sektor keuangan, industri pengolahan, pertambangan dan penggalian dan sektor pengangkutan dan komunikasi dari utang luar negeri swasta sebesar Rp. 163.592 miliar hingga mengalami kenaikan pada tahun pada tahun 2019 mengalami kenaikan sebesar Rp. 404.315 miliar yang lebih banyak dipengaruhi oleh arus masuk investasi nonresiden pada surat berharga negara (SBN) domestik dan dari sektor swasta sebesar Rp. 202.872 miliar.

Dalam upaya mengurangi ketergantungan pemerintah terhadap utang luar negeri serta menjaga tingkat pertumbuhan ekonomi, maka diperlukan cara pembayaran yang bersifat aman atas risiko utang luar negeri dan relatif produktif dalam meningkatkan pertumbuhan ekonomi, salah satu dengan cara pembayaran tersebut adalah menjual Surat Berharga Syariah Negara (SBSN) yang selanjutnya lebih dikenal dengan Sukuk (Kasmir, 2002).

Pada laporan data OJK, sukuk (Obligasi Syariah) juga menunjukan perkembangan yang positif bagi instrumen pasar modal syariah (Sukuk). Sukuk korporasi outstanding dan jumlah sukuk yang beredar mengalami perkembangan dari tahun 2014 sebesar Rp. 7.105 miliar dengan jumlah sukuk yang beredar sebanyak 35 persen sampai dengan tahun 2019 mengalami perkembangan yang positif hingga pada akhir Desember 2019 sukuk korporasi outstanding mencapai Rp. 29.829 miliar dengan jumlah sukuk yang beredar sebanyak 110 persen. Perkembangan sukuk yang sangat pesat tidak hanya dari investor muslim saja yang tertarik berinvestasi melainkan juga investor non muslim 
yang juga tertarik untuk berinvestasi. selain itu, menurut artikel (Siswantoro, 2012). Sukuk adalah salah satu instrumen keuangan yang tetap stabil ketika terjadinya krisis tahun 2008. Dikarenakan banyaknya investasi yang tertarik untuk menginvestasikan dananya pada salah satu produk pasar modal syariah yaitu sukuk.

Variabel ekonomi lainnya yang mempengaruhi pertumbuhan ekonomi yaitu inflasi, inflasi yang berarti kemerosotan nilai uang karena banyaknya uang beredar sehingga ketika inflasi naik maka harga konsumen akan naik serta barang-barang naik. Inflasi yang stabil merupakan salah satu syarat demi terciptanya pertumbuhan ekonomi yang berkesinambungan. Menurut BPS, inflasi adalah kecendrungan naiknya harga barang dan jasa secara terus menerus. Naiknya harga barang dan jasa tersebut menyebabkan turunnya nilai uang. Maka dengan demikian, inflasi juga dapat diartikan sebagai penurunan nilai uang terhadap nilai barang dan jasa secara umum atau keseluruhan. Indeks Harga Konsumen (IHK) adalah salah satu indikator untuk mengukur harga rata-rata barang dan jasa yang dikonsumsi oleh rumah tangga. Oleh karena itu, perubahan IHK dari waktu ke waktu menunjukan pergerakan harga dari barang dan jasa yang dikonsumsi masyarakat.

Berdasarkan perkembangan inflasi, Indonesia mengalami kenaikan serta penurunan angka inflasi setiap tahunnya. Pada tahun 2014 sampai tahun 2019 angka inflasi yang terbesar berada pada tahun 2014 sebesar 8.36 persen, hal tersebut dipengaruhi oleh kenaikan harga BBM bersubsidi, pada tahun 2016 dengan tingkat inflasi sebesar 3.02 persen yang dipengaruhi oleh naiknya pengeluaran masyarakat untuk membeli tiket pesawat, kecendrungan naiknya harga tiket pesawat pada musim liburan akhir tahun, pada tahun angka inflasi terendah sebesar 2.72 persen disebabkan harga-harga barang bergejolak yang relatif terkendali seperti harga beras yang pada umumnya menjadi penyebab tingginya inflasi makan pada tahun 2019 cenderung terkendali.

Untuk meredam lajunya infasi Bank Indonesia mengambil kebijakan dalam menaikkan tingkat suku bunga BI Rate. Fungsi tingkat suku bunga yaitu tabungan. Semakin tinggi suku bunga maka semakin tinggi pula keinginan masyarakat untuk menabung atau berinvestasi pada surat berharga, yang artinya semakin tinggi tingkat suku bunga maka akan semakin mendorong masyarakat untuk mengorbankan atau mengurangi tingkat pengeluaran dalam mengkonsumsi dan lebih memilih untuk menabung ataupun melakukan investasi pada surat-surat berharga, dikarenakan dapat lebih menguntungkan dari tingginya tingkat suku bunga. Tingkat suku bunga yang tinggi akan mendorong investor untuk menanam dananya di sektor perbankan daripada menginvestasikan pada sektor produksi atau industri yang memiliki tingkat resiko yang lebih besar, sehingga kegiatan pada sektor riil tidak terlalu tinggi, dengan demikian tingkat infasi dapat dikendalikan melalui kebijakan tingkat suku bunga.

Pada tahun 2014 perkembangan tingkat suku bunga lebih besar peningkatannya mencapai 7.54 persen kemudian mengalami penurunan pada tahun 2015 sebesar 7.52 persen. Pada tahun 2016 hanya sebesar 6 persen lebih kecil lalu meningkat pada tahun 2017 sebesar 4.56 persen. Pada tahun 2018 sebesar 5.10 persen sehingga pada tahun 2019 meningkat sebesar 5.62 persen. Maka dapat diketahui bahwa tingkat suku bunga di Indonesia pada lima tahun terakhir mengalami peningkatan dan penurunan. Dari tingkat suku bunga yang semakin tinggi tersebut diatas, maka akan menyebabkan permintaan mata uang suatu negara tersebut menjadi semakin meningkat.

Tingkat bunga juga dapat diartikan sebagai biaya yang harus dibayar peminjam atas pinjaman yang diterima dan merupakan imbalan bagi pemberi pinjaman atas dananya. Tingkat bunga cenderung mempengaruhi keputusan individu terhadap pilihan untuk membelanjakan uang yang lebih banyak 
Analisis utang luar negeri, sukuk, inflasi dan tingkat suku bunga terhadap pertumbuhan ekonomi indonesia

Tahun 2014-2019

atau menyimpan uang dalam bentuk tabungan di bank. Tingkat bunga digunakan suku bunga PUAB (Pasar Uang Antar Bank) untuk Indonesia dan suku bunga diskonto untuk Amerika dan Jepang (Murdayanti, 2012).

\section{TINJAUAN PUSTAKA}

\section{Pertumbuhan Ekonomi}

Pertumbuhan ekonomi adalah penambahan Produk Domestik Bruto (PDB) yang berarti penambahan pendapatan nasional. Pendapatan riil masyarakat yang lebih besar dari periode waktu sebelumnya menunjukan adanya implikasi pertumbuhan ekonomi. Untuk dapat ukuran pendapatan riil masyarakat tersebut menggunakan indikator tingkat pertumbuhan PDB (Tambunan, 2001).

Basuki (2014:87). Pertumbuhan Ekonomi dapat didefinisikan sebagai perkembangan kegiatan dalam perekonomian yang menyebabkan barang dan jasa yang diproduksikan dalam masyarakat bertambah dan kemakmuran masyarakat menjadi meningkat.

Suatu perekonomian dikatakan mengalami pertumbuhan apabila tingkat aktivitas ekonomi diwaktu tersebut lebih tinggi dari waktu sebelumnya. Dengan kata lain, perkembangan baru terjadi jika jumlah barang dan jasa secara fisik yang dihasilkan perekonomian tersebut bertambahn besar pada tahun-tahun berikutnya (Faroh, 2016).

\section{Utang Luar Negeri}

(Rachmadi, 2013) menyatakan bahwa utang luar negeri Indonesia mampu mendorong pertumbuhan ekonomi Indonesia. Sektor-sektor ekonnomi yang menyerap utang luar negeri cukup tinggi, terbukti menunjukan pertumbuhan PDB yang terus meningkat.

Menurut (Malik, Abdul, 2017), kondisi utang luar negeri pemerintah maupun pinjaman swasta menunjukan tingginya kewajiban Indonesia untuk membayar kembali pokok dan bunga pinjaman. Berikut indikator dalam mengukur beban utang yaitu :

Rasio layanan utang merupakan perbandingan antara kewajiban membayar utang dan cicilan utang luar negeri dengan devisa hasil ekspor. Ambang batas aman angka rasio layanan utang (DSR) lazimnya menurut para ahli ekonomi adalah $20 \%$. Lebih dari itu, utang sudah dianggap mengundang cukup banyak kerawanan.

Rasio utang terhadap expor merupakan rasio utang terkadap ekspor. Bank dunia menetapkan bahwa suatu negara dikatagorikan sebagai negara pengutang berat, jika negara yang bersangkutan memiliki rasio utang terhadap expor (Debt to Export Ratio) yang lebih besar dari 220\%.

Rasio utang terhadap PDB merupakan rasio utang terhadap PDB. Rasio utang terhadap PDB dapat dilihat sebagai kriteria mengecek kesehatan keuangan suatu negera, dimana rasio diatas 50\% menunjukan bahwa pinjaman luar negeri Indonesia membenahi lebih dari 50\% Pendapatan Nasional.

\section{Sukuk (Obligasi Syariah)}

Menurut Fatwa Dewan Syari'ah Nasional No:32/DSN-MUI/ IX/ 2002 Obligasi Syariah adalah suatu surat berharga jangka panjang berdasarkan prinsip syariah yang dikeluarkan oleh emiten kepada pemegang obligasi syariah yang mewajibkan emiten untuk membayar pendapatan kepada pemegang obligasi syariah berupa bagi hasil, margin atau fee serta membayar dana obligasi pada saat jatuh tempo. 
Menurut Otoritas Jasa Keuangan (OJK) mengenai penerbitan dan persyaratan sukuk, sukuk adalah Efek Syariah berupa sertifikat atau bukti kepemilikan yang bernilai sama dan mewakili bagian yang tidak terpisahkan atau tidak terbagi (syuyu'hundivided share), atas aset yang mendasarinya (www.ojk.go.id).

Berbagai jenis struktur sukuk yang dikenal secara internasional dan telah mendapatkan endorsement dari The Accounting and Auditing Organisation for Islamic Financial Institutions (AAOIFI), antara lain (Huda, Nurul, 2016) :

a. Sukuk Ijarah

Sukuk yang diterbitkan berdasarkan perjanjian atau akad Ijarah di mana satu pihak bertindak sendiri atau melalui wakilnya menjual atau menyewakan hak manfaat atas suatu aset kepada pihak lain berdasarkan harga dan periode yang disepakati, tanpa diikuti dengan pemindahan kepemilikan aset itu sendiri, Sukuk Ijarah dibedakan menjadi Ijarah-Muntahiya Battamlik (Sale and Lease Back) dan Ijarah Headlease and Sublease.

b. Sukuk Mudharabah

Sukuk yang diterbitkan berdasarkan perjanjian atau akad Mudarabah di mana satu pihak menyediakan modal (rab al-Maal) dan pihak lain menyedeiakan tenaga dan keahlian (mudarib), keuntungan dari kerja sama tersebut akan dibagi berdasarkan perbandingan yang telah disetujui sebelumnya. Kerugian yang timbul akan ditanggung sepenuhnya oleh pihak yang menjadi penyedia modal.

c. Sukuk Musyarakah

Sukuk yang diterbitkan berdasarkan perjanjian atau akad Musyarakah di mana dua pihak atau lebih bekerja sama menggabungkan modal untuk membangun proyek baru, mengembangkan proyek yang telah ada, atau membiayai kegiatan usaha. Keuntungan maupun kerugian yang timbul ditanggung bersama sesuai dengan jumlah partisipasi modal masing-masing pihak.

d. Istisna

Sukuk yang diterbitkan berdasarkan perjanjian atau akad Istsna di mana para pihak menyepakati jual beli dalam rangka pembiayaan suatu proyek atau barang. Adapun harga, waktu penyerahan dan spesifikasi proyek atau barang ditentukan terlebih dahulu berdasarkan kesepakatan.

\section{Inflasi}

Inflasi yang tinggi tingkatnya tidak akan menggalakkan perkembangan perekonomian. Biaya yang terus menerus naik akan menyebabkan kegiatan produktif sangat tidak menggantung dan para pemilik modal akan lebih senang menggunakan uangnya untuk kegiatan spekulasi (Sukirno, 2006). Ada beberapa indikator yang dapat digunakan untuk mengetahui laju inflasi selama satu periode tertentu, antara lain (Raharja, Prathama, 2004) :

Indek Harga Konsumen (IHK) adalah indeks yang menunjukan tingkat harga barang dan jasa yang harus dibeli konsumen dalam satu periode tertentu.

Indeks Harga Perdagangan Besar (IHPB) dapat dilihat dari sisi produse yang menunjukan harga yang diterima produsen dalam berbagai tingkat produksi.

Indeks Harga Implisit atau GDP deflator yang menggambarkan pengukuran level harga barang dan jasa akhir produksi dalam perekonomian suatu negara. 


\section{Tingkat Suku Bunga}

Menurut (Mankiw, 2006), bunga pada dasarnya adalah pembayaran di masa mendatang atas tranfer uang di masa lampau. Karena itu perhitungan bunga selalu melibatkan perbandingan nilai uang pada masa yang berbeda.

Suku bunga juga dapat diartikan sebagai harga yang harus dibayar kepada nasabah (yang memiliki simpanan) dengan yang harus dibayar oleh nasabah kepada bank (nasabah yang memperoleh pinjaman) (Kasmir, 2002). Dalam kegiatan perbankan sehari-hari, ada dua macam bunga yang diberikan kepada nasabahnya yaitu:

a. Bunga simpanan: bunga yang diberikan sebagai balas jasa nasabah yang menyimpan uangnya di bank. Bunga simpanan merupakan harga yang harus dibayar kepada nasabahnya. Contoh: bunga tabungan, bunga deposito dan jasa giro.

b. Bunga pinjaman: bunga atau harga yang harus dibayar oleh nasabah peminjam kepada bank. Contoh: bunga kredit.

\section{METODE}

\section{Jenis Penelitian}

Penelitian ini menggunakan data sekunder, data sekunder adalah data yang didapat secara tidak langsung atau penelitian yang memuat peristiwa masa lalu. Data sekunder dapat diperoleh dari jurnal, buku, majalah dan data statistik maupun dari internet (Bawono, 2006). Untuk memperoleh data, penelitian ini menggunakan data dari BPS, BI dan OJK dalam website resmi masing-masing lembaga.

\section{Lokasi dan Waktu Penelitian}

Penelitian ini menggunakan data sekunder dan tidak terdapat tempat penelitian, sehingga hanya mengambil objek penelitiannya saja. Dalam penelitian ini, Indonesia menjadi objek yang akan dilakukan. Waktu yang diambil dalam penelitian ini adalah kurun waktu enam tahun, dari tahun 2014 sampai tahun 2019.

\section{Sampel dan Teknik Pengambilan Sampel}

Sampel adalah objek atau subjek penelitian yang dipilih guna mewakili keseluruhan dari populasi (Bawono, 2006). Dalam penelitian ini, sampel yang digunakan berasal dari data-data pada sumber yang ada, dengan mengambil sampel selama 6 tahun sebanyak 72 data.

\section{Teknik Pengumpulan Data}

Teknik pengumpulan data yang digunakan dalam penelitian ini adalah pengumpulan data sekunder, yaitu pengambilan data yang berasal dari Badan Pusat Statistik (BPS), Bank Indonesia (BI) dan Otoritas Jasa Keuangan (OJK).

\section{Uji instrumen penelitian}

Uji instrumen penelitian dalam penelitian ini adalah dengan uji stasioner untuk menguji data sekunder. Sebuah data dapat dikatakan stasioner apabila terpenuhinya asumsi rata-rata dan variansinya konstant sepanjang waktu serta kovarian antara dua data runtut waktu tergantung pada 
Analisis utang luar negeri, sukuk, inflasi dan tingkat suku bunga terhadap pertumbuhan ekonomi indonesia

Tahun 2014-2019

kelambanan antara dua periode tersebut. Pengambilan hasil pada uji stasioner ini adalah apabila nilai probabilitasnya kurang dari atau lebih kecil dari 0,05 apabila data tersebut lebih kecil dari 0,05 maka dapat dikatakan bahwa data tersebut bersifat stasioner (Winarno, 2015).

\section{PEMBAHASAN}

\section{Pengaruh Utang Luar Negeri terhadap Pertumbuhan Ekonomi}

Berdasarkan hasil uji regresi, variabel utang luar negeri diperoleh nilai koefisien sebesar -2.38E-07 dengan arah koefisien yang positif dan nilai probabilitas menunjukan bahwa nilai signifikan sebesar $0.8238>0.05$. Dilihat dari hasil uji regresi yang menunjukan bahwa model dalam penelitian antara variabel utang luar negeri terhadap variabel pertumbuhan ekonomi berpengaruh kecil dan hasil probabilitas yang lebih besar dari 0.05 . Maka dapat disimpulkan bahwa dalam penelitian ini, utang luar negeri berpengaruh positif dan tidak signifikan terhadap pertumbuhan ekonomi sehingga hasil Hipotesis $\left(\mathrm{H}_{1}\right)$ ditolak.

Hasil penelitian ini tidak sejalan dengan penelitian (Malik, Abdul, 2017), dan penelitian (Rachmadi, 2013) yang menyatakan bahwa utang luar negeri berpengaruh secara positif dan signifikan terhadap pertumbuhan ekonomi. Serta tidak sejalan dengan penelitian yang dilakukan oleh (Kurniasari, 2017) menyatakan bahwa utang luar negeri berpengaruh negatif dan tidak signifikan. utang luar negeri Indonesia mampu mendorong pertumbuhan ekonomi Indonesia. Sektor-sektor ekonnomi yang menyerap utang luar negeri cukup tinggi, terbukti menunjukan pertumbuhan PDB yang terus meningkat.

\section{Pengaruh Sukuk terhadap Pertumbuhan Ekonomi}

Berdasarkan hasil uji regresi, variabel sukuk diperoleh nilai koefisien sebesar 5.02E-06 dengan arah koefisien yang positif dan nilai probabilitas menunjukan bahwa nilai signifikan sebesar $0.2890>0.05$. Dilihat dari hasil uji regresi menunjukan bahwa model dalam penelitian ini antara variabel sukuk terhadap variabel pertumbuhan ekonomi berpengaruh kecil dan hasil probabilitas yang lebih besar dari 0.05. Maka dapat disimpulkan bahwa sukuk berpengaruh positif dan tidak signifikan terhadap pertumbuhan ekonomi sehingga Hipotesis $\left(\mathrm{H}_{2}\right)$ ditolak.

Hasil penelitian ini tidak sejalan dengan penelitian (Faroh, 2016) yang mengatakan bahwa sukuk berpengaruh yang positif dan signifikan terhadap pertumbuhan ekonomi. Dan sejalan dengan penelitian yang dilakukan oleh (Rinanda, 2018) yang menyatakan bahwa sukuk berpengaruh positif dan tidak signifikan terhadap pertumbuhan ekonomi.

\section{Pengaruh Inflasi terhadap Pertumbuhan Ekonomi}

Berdasarkan hasil uji regresi, variabel Inflasi diperoleh nilai koefisien sebesar 0.000419 dengan arah koefisien yang positif dan nilai probabilitas menunjukan bahwa nilai signifikan sebesar $0.9884>0.05$. Dilihat dari hasil uji regresi menunjukan bahwa model dalam penelitian ini antara variabel inflasi terhadap variabel pertumbuhan ekonomi berpengaruh kecil dan hasil probabilitas yang lebih besar dari 0.05. Maka dapat disimpulkan bahwa inflasi berpengaruh positif dan tidak signifikan terhadap pertumbuhan ekonomi karena sehingga Hipotesis $\left(\mathrm{H}_{3}\right)$ ditolak. 
Analisis utang luar negeri, sukuk, inflasi dan tingkat suku bunga terhadap pertumbuhan ekonomi indonesia

Tahun 2014-2019

Hasil penelitian ini tidak sejalan dengan penelitian yang dilakukan oleh (Rachmadi, 2013) yang menyatakan bahwa inflasi tidak berpengaruh signifikan terhadap pertumbuhan ekonomi Indonesia. Dan tidak sejalan dengan penelitian (Septiatin, 2016) menyatakan bahwa inflasi tidak berpengaruh signifikan terhadap pertumbuhan ekonomi. Serta tidak sejalan dengan penelitian Susanto (2012) menyatakan bahwa inflasi berpengarih positif dan signifikan terhadap pertumbuhan ekonomi. Inflasi yang tinggi tingkatnya akan menggalakkan perkembangan perekonomian. Biaya yang terus menerus naik akan menyebabkan kegiatan produktif sangat tidak menggantung dan para pemilik modal akan lebih senang menggunakan uangnya untuk kegiatan spekulasi

\section{Pengaruh Tingkat Suku Bunga terhadap Pertumbuhan Ekonomi}

Berdasarkan hasil uji regresi, variabel tingkat suku bunga diperoleh nilai koefisien sebesar -0.038532 dengan arah koefisien yang positif dan nilai probabilitas menunjukan bahwa nilai signifikan sebesar $0.0029>0.05$. Dilihat dari hasil uji regresi yang menunjukan bahwa model dalam penelitian ini antara variabel tingkat suku bunga terhadap variabel pertumbuhan ekonomi berpengaruh kecil dan hasil probabilitas yang lebih besar dari 0.05. Maka dapat disimpulkan bahwa tingkat suku bunga berpengaruh positif dan tidak signifikan terhadap pertumbuhan ekonomi sehingga Hipotesis $\left(\mathrm{H}_{4}\right)$ ditolak.

Hasil penelitian ini tidak sejalan dengan penelitian yang dilakukan oleh (Pratiwi, 2015) menyatakan bahwa inflasi berpengaruh positif dan signifikan terhadap pertumbuhan ekonomi. Serta tidak sejalan dengan penelitian (Fitria, 2018) yang menyatakan bahwa inflasi berpengarih positif dan tidak signifikan terhadap pertumbuhan ekonomi.

\section{KESIMPULAN}

Berdasarkan hasil uji analisis data maka pengujian hipotesis dan pembahasan yang telah diuraikan dapat diambil kesimpulan bahwa utang luar negeri, sukuk, inflasi dan tingkat suku bunga berpengaruh positif dan tidak signifikan terhadap pertumbuhan ekonomi. Sektor-sektor ekonnomi yang menyerap utang luar negeri cukup tinggi, terbukti menunjukan pertumbuhan PDB yang terus meningkat. Sedangkan pengaruh inflasi terhadap perekonomian adalah biaya yang terus menerus naik akan menyebabkan kegiatan produktif sangat tidak menggantung dan para pemilik modal akan lebih senang menggunakan uangnya untuk kegiatan spekulasi

\section{DAFTAR PUSTAKA}

Asyafiq, S. (2019). Strategi Pertumbuhan dan Pembangunan Ekonomi di Era Global berbasis Pendidikan Ekonomi Kewarganegaraan. Jurnal Pendidikan Ilmu Sosial.

Faroh, N. (2016). Pengaruh Saham Syariah, Sukuk dan Reksadana Syariah terhadap Pertumbuhan Ekonomi Nasional Tahun 2008-2015. Skripsi IAIN Tulung Agung , 34.

Kasmir. (2002). Bank dan Lembaga Keuangan Lainnya. Jakarta: PT. Raja Grafindo Persada. 
Analisis utang luar negeri, sukuk, inflasi dan tingkat suku bunga terhadap pertumbuhan ekonomi indonesia Tahun 2014-2019

Murdayanti, Y. (2012). Pengaruh Gross Domestic Product, Inflasi, Suku Bunga, Money Supply, Current Account dan Capital Account terhadap Nilai Rupiah Indonesia- Dollar Amerika.

Siswantoro, D. (2012). The Case of Islamic (Sukuk) Mutual Funds in Indonesia During Financial Crisis. Jurnal of Islamic Accounting and Business Research, 163.

Tambunan, T. H. (2001). Perekonomian Indonesia. Bogor: Ghalia Indonesia. 